\title{
Prilog I. \\ O novome na Desničinim susretima 2013.
}

Osim po inovativnim izlaganjima i raspravama, Desničini susreti 2013. ostat će upamćeni i po programskim novinama - dvjema izložbama, književnoj večeri i filmskoj projekciji. Uz novine zadržala se i tradicija predstavljanja knjiga proizašlih iz aktivnosti povezanih s Desničinim susretima.

U četvrtak, 19. rujna 2013. u Gradskoj knjižnici Zadar otvorena je izložba posvećena Vladanu Desnici i Desničinim susretima. Autori izložbe bili su prof. dr. sc. Drago Roksandić i Ivana Cvijović Javorina. Na njihov je prijedlog Znanstvena knjižnica u Zadru organizirala izložbu o književnom opusu Vladana Desnice te o čitateljskoj i kritičarskoj recepciji njegovih djela. ${ }^{1}$

U sklopu programa otvaranja Desničinih susreta 2013. u petak, 20. rujna 2013. premijerno je prikazan srednjometražni film Intelektualac danas u trajanju od oko 40 minuta. Djelo je nastalo sa željom da se i pomoću audiovizualnog medija filma približe, prouče i kritički preispitaju neka pitanja vezana uz današnji položaj intelektualaca i njihovu samoidentifikaciju. Autori filma polustrukturiranim su intervjuima predstavili publici odabrani niz intelektualaca s različitih područja znanosti, umjetnosti i masovnih medija, pokušavajući pronaći zajedničke točke, ali i točke razilaženja intelektualaca današnjice. Ovaj je film prema zamisli redatelja i autora prvi u nizu kratkometražnih i srednjometražnih filmova. Prikazani dio sadržava razgovore s akademikom Josipom Bratulićem, umjetnikom Vladimirom Dodigom Trokutom, prof. dr. sc. Tomislavom Premerlom, doc. dr. sc. Vladimirom Rismondom ml. i prof. dr. sc. Feđom Vukićem. $\mathrm{Na}$ filmu su surađivali studenti i doktorandi, kojima je ovo uglavnom bio i filmski prvijenac. Autori filma su Nikolina i Filip Šimetin Šegvić te Marta Fiolić. U radu na filmu sudjelovali su i Ines Jambrek, Bruno Režek i Valentina Nedeljko.

Iste je večeri u Gradskoj knjižnici Zadar održana književna večer pod nazivom Dva pogleda na poetski opus Vladana Desnice, na kojoj su prof. dr. sc. Helena Peričić i akademik Tonko Maroević iznijeli svoj pogled na liriku Vladana Desnice. Poezija Vladana Desnice rjeđe privlači pozornost čitatelja i kritičara pa su ova dva renomirana poznavatelje Desničina opusa aktualizirala trajnije vrijednosti njegova pjesničkog stvaralaštva. ${ }^{2}$ Odabrane dijelove Desničine poezije čitala je studentica Marta Fiolić.

U subotu, 20. rujna 2013. u Gradskoj knjižnici Zadar predstavljena su tri nova naslova Centra za komparativnohistorijske i interkulturne studije i FF pressa objavljena u bibliotekama Desničini susreti i Dijalog s povodom: Intelektualci i rat 1939.-1947. Zbornik radova s medunarodnog skupa Desničini susreti 2012. (ur. Drago Roksandić i Ivana Cvijović), Intelektualna historija (prir. Branimir Janković) i Slika u povijesti, povijest u slici: "pokretna" historija (Marc Ferro, Tomislav Branđolica, Marko Lovrić i Filip Šimetin Šegvić). ${ }^{3}$

Desničini susreti 2013. zaključeni su u Kuli Stojana Jankovića projekcijom filma Pravda (1962.). Film nastao prema istoimenoj noveli Vladana Desnice režirao je Ante Babaja, a glavne uloge tumače Boris Festini, Ivo Kadić i Vanča Kljaković. Kinoteka Hrvatskoga državnog arhiva u Zagrebu restaurirala je ovaj film 1997. godine. Prava na prikazivanje osigurao je Zagreb film, a do samog se filma za potrebe ove projekcije došlo u suradnji s Hrvatskim državnim arhivom.

$1 \quad$ Usp. tekst Ivane Cvijović Javorina u ovome zborniku, str. 227.

2 Usp. tekst Helene Peričić u ovome zborniku, str. 213. Tonko Maroević je već ranije u zborniku s Desničinih susreta objavio tekst o poeziji Vladana Desnice. Usp. Tonko Maroević, "Zgusnute kaplje. Pretpostavke za čitanje Desničinih stihova”, Desničini susreti 2005. - 2008. (ur. Drago Roksandić i Ivana Cvijović Javorina), Zagreb 2010., 16-25.

3 O navedenim izdanjima više u Drago Roksandić - Ivana Cvijović Javorina (ur.), Desničini susreti i Kula Stojana Jankovića: Iskustva i razvojne mogućnosti, Zagreb 2014., 40-42 i 57-60. 


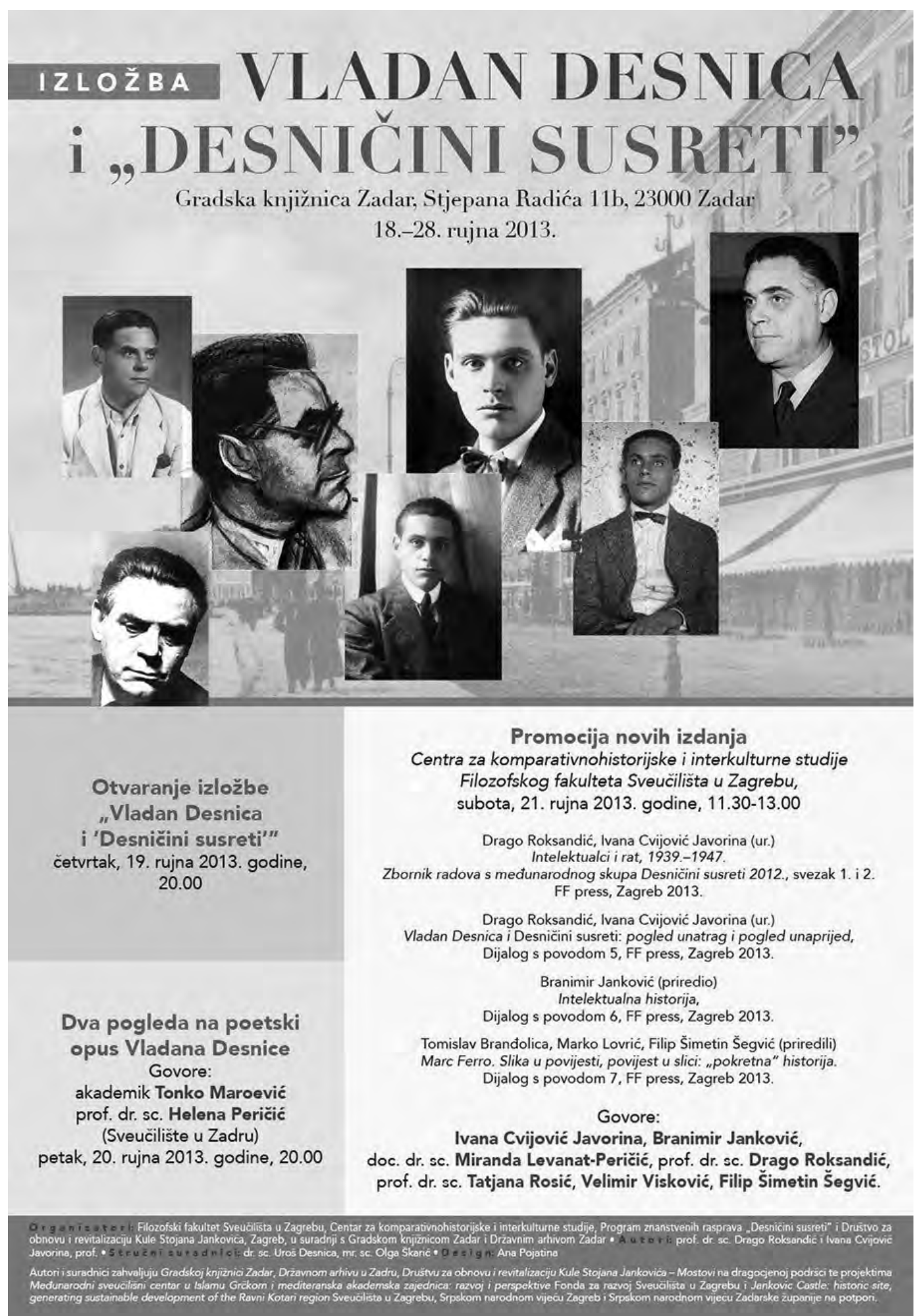

Sl. 2. Novi sadržaji na Desničinim susretima 2013.: izložba i književna večer. Design: Ana Pojatina 